\title{
PERIOD3 gene P415A/H417R polymorphism-linked familial advanced sleep phase
}

\section{Chidiebere Emmanuel Okechukwu(D)}

Evidence of transcriptional investigations in human medicine showed that significant segments of the genome are regulated by the circadian clock, and more than half of protein-encoding genes exhibit circadian oscillation in different forms across tissues [1]. There is a strong association between the circadian clock gene PERIOD3 (PER3) P415A/H417R variants and familial advanced sleep phase (FASP) [2]. The P415A and H417R are rare variants of PER3 gene. The PER3-P415A/H417R polymorphism may alter the period of circadian clock oscillation. FASP is a rare autosomal dominant trait and human behavioral phenotype [3]. One feature that differentiates FASP from advanced sleep phase disorder is its robust familial trend and lifetime expression. Genetic sequencing analysis of affected lineages revealed that nearly $50 \%$ of related family members have FASP [4]. Individuals with FASP usually have a short circadian period, an advanced circadian phase, phase-advanced plasma melatonin levels and body core temperature rhythms, and a typical morning chronotype [3]. Individuals with FASP experience constant early evening sleep onset and early morning awakening [5].

Ever since Dr Zhang and colleagues [2] showed a robust association between PER3-P415A/H417R variants, FASP, and related seasonal affective disorder (SAD), no other scientific investigation has been carried out to unravel more information regarding the underlying pathophysiology, and relationship between PER3-P415A/ H417R polymorphism, FASP, and mood disorders. The PER3-P415A/H417R polymorphism was detected in genetic sequencing analysis, and SAD was also diagnosed in individuals with FASP. Moreover, SAD is a seasonal pattern of recurring major depressive periods that

Correspondence: chidiebere.okechukwu@uniroma1.it

Department of Public health and Infectious Diseases, Sapienza University of Rome, Piazzale Aldo Moro 5, 00185 Rome, Italy frequently occur during autumn or winter and drops in spring [6]. Dr Zhang and colleagues infused the PER3$\mathrm{P} 415 \mathrm{~A} / \mathrm{H} 417 \mathrm{R}$ variants on mice, and the mice showed symptoms of depression and poor sleep quality, suggesting an association between the P415A/H417R missense mutations and mood disorders, hence demonstrating a relationship between poor sleep quality and depression.

The P415A and H417R missense mutations in the PER3 gene occur on the same allele, a C-to-G transversion resulting in the substitution of proline for alanine at position 415, and an A-to-G transition resulting in the substitution of histidine for arginine at position 417 [2]. The two missense heterozygous mutations in the PER3 gene were mapped at chromosome 1p36.23. The PER3$\mathrm{P} 415 \mathrm{~A} / \mathrm{H} 417 \mathrm{R}$ variants function as a link, connecting the regulatory processes of circadian rhythms with those of mood, and it partakes in the modulation of these processes to adjust to the short photoperiods during winter. Expression of the variant allele in transgenic mice resulted in a longer circadian period under constant light, and phase shifts of the sleep-wake cycle in a shorter light period, as detected in winter, and increased depression. The mutant protein was also expressed at levels lower than the control values, due to decreased stability, and the failure to stabilize the PERIOD1 and PERIOD2 proteins, which play vital roles in circadian timing. There are few studies that reported on the prevalence of PER3 gene polymorphism in different ethnic groups worldwide. According to the outcome of a study conducted in Brazil, the allele frequency of 4 repeats in the PER3 gene was much higher in Asians than Caucasians, and this might be attributed to evolutionary processes that have reformed these genetic patterns in diverse ethnic groups [7]. However, Nadkarni et al. did not observe any significant variation in the pattern of PER3 allele frequencies among European American, African American, and East 
Asian populations [8]. One study that examined the association between sleep duration and mood traits in PER3 genotype groups among Brazilian families living in Baependi, a small rural town in Brazil, showed an association between PER3 genotype, sleep duration and depression symptoms [9].

In conclusion, genetic testing to detect PER3-P415A/ H417R polymorphism during genetic sequencing analysis in individuals and families with symptoms of advanced sleep phase disorder or SAD is important in the diagnosis of FASP. However, further studies on FASPrelated PER3-P415A/H417R variants will offer more clue on the association between sleep-wake cycle, extreme diurnal preference in arousal and activity, and mood regulation. Furthermore, advanced laboratory and clinical investigations on PER3-P415A/H417R polymorphismlinked FASP may present evidence on how to develop pharmaceutical agents to target depression associated with poor sleep quality due to the disruption of the circadian clock. Moreover, there is a need to conduct large experimental studies concerning PER3 gene polymorphism in different ethnic groups around the world.

\section{Abbreviations \\ PER3: PERIOD3; FASP: Familial advanced sleep phase; SAD: Seasonal affective disorder}

\section{Acknowledgements}

Not applicable.

\section{Author's contributions}

CEO did the literature search, wrote the manuscript, drafted the manuscript, and revised the manuscript critically. The author read and approved the final manuscript.

\section{Funding}

There was no funding received for this study.

Availability of data and materials

Not applicable.

\section{Declarations}

Ethics approval and consent to participate

Not applicable.

\section{Consent for publication}

Not applicable.

\section{Competing interests}

The author declares that he has no conflict of interest.

Received: 31 March 2021 Accepted: 14 May 2021

Published online: 14 June 2021

\section{References}

1. Allada R, Bass J (2021) Circadian mechanisms in medicine. N Engl J Med 384(6):550-561. https://doi.org/10.1056/NEJMra1802337

2. Zhang L, Hirano A, Hsu PK, Jones CR, Sakai N, Okuro M, McMahon T, Yamazaki M, Xu Y, Saigoh N, Saigoh K, Lin ST, Kaasik K, Nishino S, Ptáček LJ, Fu YH (2016) A PERIOD3 variant causes a circadian phenotype and is associated with a seasonal mood trait. Proc Natl Acad Sci U S A 113(11): E1536-E1544. https://doi.org/10.1073/pnas.1600039113
3. Reid KJ, Chang AM, Dubocovich ML, Turek FW, Takahashi JS, Zee PC (2001) Familial advanced sleep phase syndrome. Arch Neurol 58(7):1089-1094. https://doi.org/10.1001/archneur.58.7.1089

4. Tafti M, Dauvilliers Y, Overeem S (2007) Narcolepsy and familial advanced sleep-phase syndrome: molecular genetics of sleep disorders. Curr Opin Genet Dev 17(3):222-227. https://doi.org/10.1016/j.gde.2007.04.007

5. Liberman AR, Kwon SB, Vu HT, Filipowicz A, Ay A, Ingram KK (2017) Circadian clock model supports molecular link between PER3 and human anxiety. Sci Rep 7(1):9893. https://doi.org/10.1038/s41598-017-07957-4

6. Forneris CA, Nussbaumer B, Kaminski-Hartenthale A, Morgan LC, Gaynes BN, Sonis JH et al (2015) Psychological therapies for preventing seasonal affective disorder. Cochrane Database Syst Rev 5:CD011270

7. Barbosa AA, Pedrazzoli M, Koike BD, Tufik S (2010) Do Caucasian and Asian clocks tick differently? Braz J Med Biol Res 43(1):96-99. https://doi.org/10.1 590/50100-879X2009007500022

8. Nadkarni NA, Weale ME, von Schantz M, Thomas MG (2005) Evolution of a length polymorphism in the human PER3 gene, a component of the circadian system. J Biol Rhythm 20(6):490-499. https://doi.org/10.1177/074 8730405281332

9. Ruiz FS, Beijamini F, Taporoski TP, Pereira AC, Knutson KL, Pedrazzoli M et al (2019) P041 PER3 polymorphism, sleep duration and depression symptoms in a brazilian family-based cohort, the Baependi heart study. BMJ Open Respir Res 6(Suppl 1):A1-A50

\section{Publisher's Note}

Springer Nature remains neutral with regard to jurisdictional claims in published maps and institutional affiliations.

\section{Submit your manuscript to a SpringerOpen ${ }^{\circ}$ journal and benefit from:}

- Convenient online submission

- Rigorous peer review

- Open access: articles freely available online

- High visibility within the field

- Retaining the copyright to your article

Submit your next manuscript at $\boldsymbol{\nabla}$ springeropen.com 